\title{
KONTRAKSI OTOT SKELET
}

\author{
Madri. M, Drs, M.Kes, AIFO \\ Program Studi Pendidikan Jasmani KEsehatan dan Rekreasi Jurusan \\ Pendidikan Olahraga Fakultas Ilmu Keolahragaan Universitas
}

\begin{abstract}
Secara mekanisme kontraksi otot adalah terjadinya sliding filamen, sedangkan rangkaian proses kontraksi secara sederhana merupakan (1) adanya rangsangan dari otak melalui akson neuron motorik keserabut otot, (2) asetilkolin yang berada disynaptic gutter akan berikatan dengan reseptornyapada sarkolema, sehingga terjadi depolarisasi membran dan menimbulkan potensial aksi sel otot rangkaserta menyebabkan ion natrium dan kalium keluar, dan (3) potensial aksi yang disebarkan dari membran sel akan diteruskan melalui tubulus $\mathrm{T}$, selanjutnya merangsang terminal sisterna sarkoplasmik retikulumuntuk melepaskan ion kalsium. Ion kalsium akan berikatan dengan troponin Cpada filamen aktin dan mendorong filamen tropomiosin menutup celah-celah aktivesite filamen aktin, sehingga aktivesite terbuka.

Otot merupakan jaringan peka yang dapat dirangsang untuk menimbulkan suatu potensial aksi. Otot rangka melekat pada tulang dan berperan sebagai sistem perototan yang menggerakan tubuh. Aktivitas otot diatur oleh susunan saraf melalui persarafan motorik. Otot rangka tersusun dari serat-serat yang merupakan balok penyusun (building bloks) sistem otot. $40 \%$ dari berat badan manusia terdiri dari otot rangka dan $10 \%$ terdiri dari otot polos dan jantung. Mekanisme kontraktil ototrangka tergantung dari protein miosin, aktin, troponin dan tropomiosin. Ciri filamen miosin tebal, sedangkan filamen aktin tipis. Sebagian saling bertautan sehingga menyebabkan myofibril secara bergantian menunjukan pita terang dan gelap. Pita ini saling tumpang tindih dan terjadi penonjolan dari sisi filamen miosin. Penonjolan ini dinamakan jembatanpenyeberangan (cross bridge).
\end{abstract}

\section{Kata Kunci : Mekanisme kontraksi otot, sliding filamen, miosin, aktin, troponin dan tropomiosin}




\begin{abstract}
The mechanism of muscle contraction is the occurrence of sliding filaments, whereas the simple process of contraction is (1) the stimulation of the brain through the axon motor neuron muscle fibers, (2) acetylcholine disynaptic gutter binds to its receptor in sarcolemma, resulting in membrane depolarization and infusing the skeletal muscle cell action potential and causing sodium and potassium ions to pass, and (3) the action potential propagated from the cell membrane will be passed through the $\mathrm{T}$ tubule, further stimulating the reticulum sarcoplasmic systernal terminal to release calcium ions. The calcium ion binds to troponin $\mathrm{C}$ on the actin filament and pushes the filaments of tropomiosin to close the activesite filaments of the actin filaments, allowing open acetite.

Muscles are sensitive tissues that can be stimulated to give rise to an action potential. Skeletal muscle is attached to the bone and acts as a muscular system that moves the body. Muscle activity is governed by the nervous system through motor innervation. Skeletal muscles are composed of fibers that are the building blocks of the muscular system. $40 \%$ of the human body weight consists of skeletal muscle and $10 \%$ consists of smooth muscle and heart. The contractile mechanism of skeletal muscle depends on the myosin, actin, troponin and tropomiosin proteins. The feature of the myosin filaments is thick, while the actin filaments are thin. Some are interlocked causing myofibrils to alternately show bright and dark bands. These bands overlap and there is protrusion from the side of the myosin filaments. This protrusion is called a cross bridge
\end{abstract}

Keywords:Mechanism of muscle contraction, sliding filament, myosin, actin, troponin and tropomyosin 


\section{A. PENDAhuluan.}

Sel-sel otot seperti juga neuron dapat dirangsang secara kimiawi, listrik dan mekanik untuk membangkitkan potensial aksi yang dihantarkan sepanjang membran sel. Berbeda dengan neuron, otot memiliki mekanisme kontraktil yang digiatkan oleh potensial aksi. Protein kontraktil seperti aktin dan miosin yang menghasilkan kontraksi terdapat dalam jumlah yang sangat banyak di otot. Namun protein kontraktil juga ditemukan hampir disemua sel tubuh. Miosin adalah salah satu penggerak molekuler yang mengubah energi hasil hidrolisis ATP menjadi gerakan suatu komponen selular disepanjang komponen lainnya. (Ganong, 1999). Lebih lanjut Ganong mengatakan bahwa secara umum otot dibagi atas tiga jenis yaitu : otgot rangka, otot jantung dan otot polos. Otot rangka merupakan massa yang besar menyusun jaringan otot somatik.

Guyton, 1995. mengatakan bahwa $40 \%$ dari berat badan manusia terdiri dari otot rangka dan
$10 \%$ terdiri dari otot polos dan jantung. Pada dasarnya mekanisme kontraksi ke tiga jenis otot ini hampir sama. Otot rangka melekat pada tulang dan berperan sebagai sistem perototan yaitu menggerakan tubuh. Gambaran garis lintang sangat jelas, tidak berkontraksi tanpa adanya rangsangan dari saraf, tidak ada hubungan anatomik dan fungsional sel-selnya dan secara umum dikendalikan oleh kehendak (volunter). Otot jantung juga berpola garis lintang, tetapi membentuk sinsitium fungsional, dapat berkontraksi ritmis walaupun tanpa persarafan eksternal, karena adanya sel-sel picu dimiocardium yang mencetuskan impuls spontan. Otot polos tidak memperlihatkan gambaran garis lintang dan ditemukan hampir disemua alat visera yang berongga, membentuk sinsitium fungsional dan memiliki sel-sel picu yang melepaskan impuls tidak teratur (Ganong, 1999). Untuk mengetahui mekanisme kerja otot rangka, lebih dahulu perlu diketahui anatomi otot tersebut.

AnatomiMorfologi otot skelet. 
Otot rangka tersusun dari serat-serat yang merupakan balok penyusun (building bloks) sistem otot dalam arti yang sama dengan neuron merupakan balok penyusun sistem saraf. Bagian luar dari otot ini dilapisi jaringan ikat yang disebut epimisium. Otot terdiri dari gugusan kecil disebut fasikulus. Pada fasikulus dilapisi oleh jaringan ikat disebut ferimisium dan dibentuk oleh kumpulan serabut otot (muscle fiber) yang jumlahnya dapat mencapai ratusan. Setiap serat dilengkapai dengan jaringan ikat disebut endomisium. Sel otot yang berbentuk selindrik panjang merupakan sebuah serabut otot mempunyai ukuran bervariasi antara 1-40 $\mathrm{mm}$ dan garis tengah antara 10-80 mikron. Sebaliknya masing-masing serabut otot terdiri dari banyak sub unit yang lebih kecil (Guyton, 1995). Serabut otot diliputi oleh membran sel yang dinamakan sarkolema. Antara selselnya tidak terdapat jembatan sinsitium. Serat-serat otot tersusun atas myofibril yang terbagi menjadi filamen-filamen. Filamen-filamen ini tersusun dari protein kontraktil (Ganong, 1999).

Mekanisme kontraktil otot rangka tergantung dari protein miosin, aktin, troponin dan tropomiosin. Troponin terdiri dari tiga sub unit yaitu troponin I, T \& C. Ke tiga sub unit tersebut mempunyai berat molekul berkisar 18.000 s/d 35.000. Protein lain, aaktin yang mempunyai berat molekul 190.000 mengikat aktin pada garis Z. Protein-protein lain berperan penting dalam meneruskan eksitasi menjadi kontraktil (Ganong, 1999). Pada ujung-ujung serabut otot bersatu dengan serabutserabut tendo dan kemudian melekat pada tulang. Tiap serabut terletak berdampingan sekitar 1500 filamen miosin dan 3000 filamen aktin yang merupakan molekuk protein polimer besar yang bertanggung jawab untuk kontraksi otot (Guyton, 1995). Ciri filamen miosin tebal, sedangkan filamen aktin tipis. Sebagian saling bertautan sehingga menyebabkan myofibril secara bergantian menunjukan pita terang dan gelap. Pita ini saling tumpang tindih dan terjadi 
penonjolan dari sisi filamen miosin.

Penonjolan ini dinamakan

jembatanpenyeberangan (cross

bridge). Interaksi antara jembatan

penyeberangan dengan filamen aktin

menyebabkan kontraksi otot.

Filamen aktin dan filamen miosin yang terletak pada membran atau garis $\mathrm{Z}$ dan bagian diantara dua garis $\mathrm{Z}$ dinamakan sarkomer (Guyton,1995). Anatomi otot rangka dapat dilihat pada gamber berikut ini :

Organization of skeletal muscle from the gross to the molecular, F, G, $\mathrm{H}$ and $\mathrm{I}$ are cross-section at the levels indicated (Drawing by Sylvia Colasd Keene. Modified from Fawcett : Bloom and Fawcett A: Texbook of Histologi, Philadelphia)

\section{B. PEMBAHASAN}

Perbedaan indeks refraksi dari berbagai bagian serat otot memberikan gambaran garis lintang yang khas pada otot rangka. Bagian-bagian dari pola luriklintang diberi tanda dengan huruf. Pita I yangtterang-terbagi oleh garis yang gelap tampak pita $\mathrm{H}$ yang (diantara serat) lebih terang. Garis lintang M tampak ditengah pita $\mathrm{H}$ dan garis ini dengan daerah terang yang sempit Perimisium

ser didkedua sisinya kadang dinamakan Inti daerah pseudo-H. Daerah antara dua mengelilingi masing

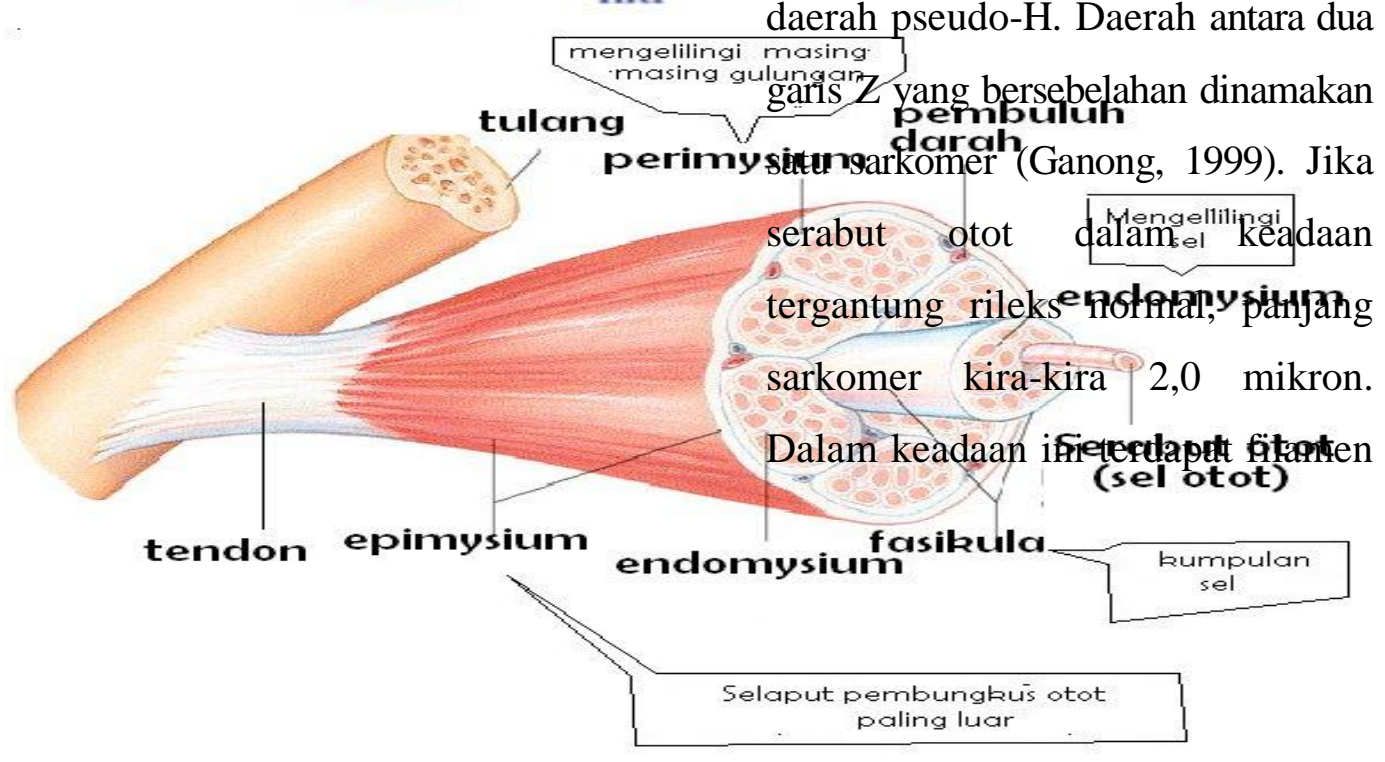


aktin dan miosin yang letaknya berdampingan. Jika otot rileks ujung filamen aktin menjahui sesamanya dan timbulah daerah terang ditengah bagian A. Daerah inilah yang disebut zone $\mathrm{H}$. Dalam keadaan kontraksi zone $\mathrm{H}$ tidak akan kelihatan, karena perubahan panjang pada sarkomer (berkisar 2,0 s/d 1,6 mikron). Perubahan ini menyebabkan letak filamen aktin dan miosin berdampingan. Letak myofibril pada waktu kotraksi dan relaksasi berbeda.

Filamen tebal berdiameter \pm 2 $\mathrm{x}$ diameter filamen tipis, tersusun dari miosin, filamen tipis tersusun dari aktin, tropomiosin dan troponin. Filamen tebal berjajar membentuk pita A, sedangkan susunan filamen tipis membentuk pita I yang kurang padat. Pita $\mathrm{H}$ yang lebih terang ditengah pita A merupakan daerah pada keadaan relaksasi. Filamen-filamen tipis tidak tumpang tindih denganfilamen tebal. Garis Z merupakan gafis potong fibril dan menghubungkan filamen-fizamen tipis. Bila spita A dipotongt filamen tebal dikelilingi 6 filamen tipis dengan pola heksagonal yang teratur (Ganong,1999). Susunan filamen tebal dan tipis dapat dilihat pada gambar berikut :

Diagram susunan aktin, tropomiosin dan ketiga unit troponin (I,C,T)

Susunan serta pergeseran filamen tipis (aktin) dan tebal (miosin) selama kontraksi otot rangka.

Sarkolema mengandung banyak ion kalsium, magnisium, fosfat dan enzym-enzym. Juga terdapat mitokondria dalam jumlah besar yang terletak diantara miofibril. Pada mitokondria inilah dibentuk ATP (Adenosin Trifosfat)

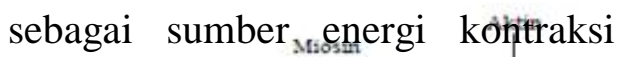
otot. Sarkolemąa lakân melakukan perluasan-ke carah dalam sẹbagai tubulus $\mathrm{T}$, gelohnbakth depolarisasi mikroskop elektron tampak bahwa Troponin

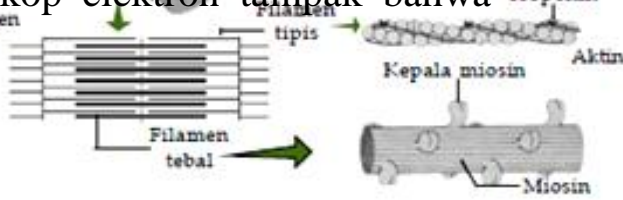


selama proses eksitasi dapat mencapai miofibril yang terletak dibagian dalam. Diantara miofibril terdapat retikulum sarkoplasma, yang merupakan struktur yang memegang peranan penting dalam proses kontraksi. Otot-otot yang melakukan kontraksi dengan cepat mempunyai retikulum sarkoplasma yang lebih banyak. Pada ujung retikulum sarkoplasma akan melebar sebagai terminal sisterna. Posisinya sangat dekat dengan tubulus $T$. Struktur ini sangat besar peranannya dalam proses kontraksi karena berfungsi sebagai saluran $\mathrm{Ca}$ (Ca chanel). Fungsi retikulum sarkoplasma adalah melepaskan ion $\mathrm{Ca}$ (calsium) selama proses relaksasi.

\section{Myofilamen.}

\section{Miosin.}

Miosin merupakan senyawa/kompleks protein yang berikatan dengan aktin. Jenis miosin yang terdapat di otot adalah dalam bentuk miosin II dengan dua kepala berbentuk globular serta ekor yang panjang dan memiliki aktivitas ATPase. Molekul miosin I memiliki sebuah kepala dan sebuah ekor yang panjangnya bervariasi. Bersama aktin, miosin I sering berikatan dengan membran sel ( Ganong, 1999).

Filamen miosin terdiri dari 200 molekul miosin dengan berat molekul 480.000 (Guyton, 1995). Molekul miosin terdiri dari 6 (enam) rantai polipeptida yang terdiri dari 2 rantai berat (heavy chains) dan 4 rantai ringan ( light chains). Rantairantai tipis dan bagian $\mathrm{N}$ terminal rantai tebal bergabung membentuk kepala globular (miosin head). Pada kepala globular ini terdapat tempattempat yang dapat berikatan dengan aktin ( Aktinbinding site) dan bagian-bagian yang bersifat katalik yang dapat menghidrolisis ATP. Molekul miosin tersusun simetris di kedua sisi tengah sarkomer dan susunan inilah yang membentuk gambaran daerah terang dipseudo-H. Adanya garis $\mathrm{M}$ disebabkan oleh adanya tonjolan (bulge) di tengah filamen tebal. 
Ditempat tersebut ditemukan penghubung melintang yang tipis dan mengikat menjaga keteraturan susunan filamen tebal. Terdapat ratusan molekulmiosin dalam segmen tebal. Filamen tipis terdiri dari dua rantai unit globular yang membentuk double heliks yang panjang (Ganong, 1999). Susunan miosin dapat dilihat pada gambar berikut (Guyton,1995).

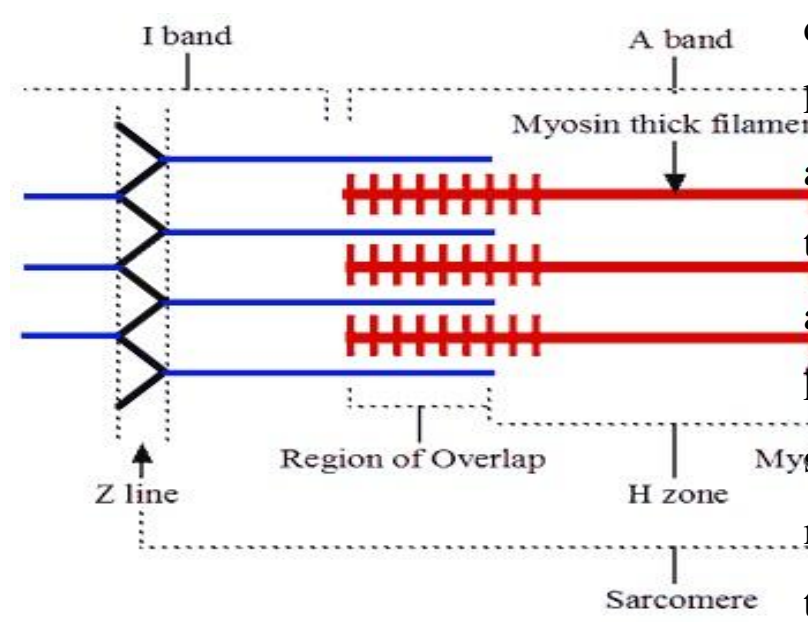

Struktur Filamen miosin (Brooks,1985,

Guyton,1995)

\section{Aktin.}

Aktin terdiri dari 3 unsur yaitu aktin, tropomiosin dan troponin. Filamen aktin berutas ganda, kedua utas melilit dalam satu heliks. Tiap utas terdiri dari polimerisasi molekul Gaktin, masing-masing mempunyai berat 42.000 . (Guyton, 1995). Tiap molekul G-aktin (globular) melekat satu molekul ADP. Ini merupakan aktivesite filamen aktin dimana jembatan penyeberangan saling mengadakan interaksi untuk kontraksi otot. Utas tropomiosin mengandung protein tambahan yang merupakan polimer molekul tropomiosin. Tiap utas terikat

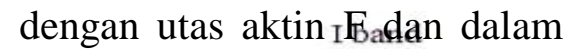

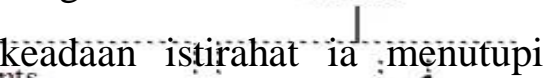
akt vesite utas aktin, sehingga ITITH tidak aktinmiosin untuk menkibulkan kontraksi. Treponin sebagai Mysalahrossatidge protein tglobular mempunyai afinitas yạng kuat terhadap aktin, thtropomriosin dan kalsium. Ini adalah awal proses kontraksi. Susunan aktin dan proses peningkatan calsium dapat dilihat sebagai berikut (Broke, 1985, Guyton,1995).

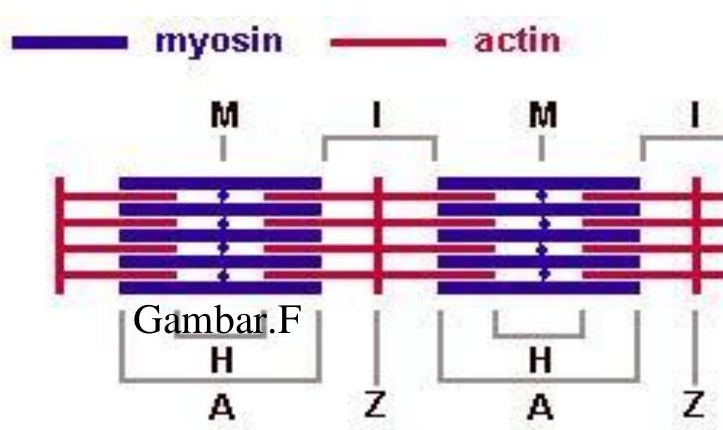

Bands and lines in the cont apparatus of skeletal mu 
Susunan Filamen Aktin dan proses peningkatan ion $\mathrm{Ca}$

(Brooks, 1985)

\section{Troponin.}

Molekul troponin merupakan unit-unit kecil globular dengan jarak ter-tentu disepanjang molekul tropomiosin. Troponin $\mathrm{T}$ mengikat komponen troponin lain pada tropomiosin. Troponin-I menghalangi interaksi miosin dengan aktin dan troponin $\mathrm{C}$ mengandung tempat pengikatan untuk $\mathrm{Ca}^{2+}$ yang akan menimbulkan kontraksi. (Ganong, 1999). Troponin terdiri dari 3 jenis protein yaitu troponin-I $\mathrm{T}$, dan troponin C. Ia terikat dengan tropomiosin sehingga membentuk troponin-tropomiosin kompleks. Troponin $\mathrm{T}$ mempunyai afinitas yang tinggi terhadap tropomiosin, troponin $\mathrm{C}$ terhadap ion $\mathrm{Ca}$ dan troponin-I terhadap molekul aktin. Hanya molekul aktin dan miosin yang secara langsung terlibat dalam proses kontraksi, sedangkan troponin dan tropomiosin hanya mengatur interaksi tersebut, sehingga disebut sebagai regulatori protein.

\section{Tropomiosin.}

\section{Molekul-molekul}

tropomiosin merupakan filamen panjang yang terletak disepanjang alur antara dua rantai aktin. Tiap filamen tipis mengandung 300-400 molekul aktin dan 40-60 molekul tropomiosin (Ganong, 1999).

Molekul tropomiosin ini terdiri dari dua rantai helex yang berhubungandengan aktin $\mathrm{F}$ dan berjalan seperti spiral mengelilingi aktin F. Dalam keadaan istirahat terletak pada bagian atas filamen aktin yang aktif (activesite-actin), dan hal ini mencegah interaksi antara molekul aktin dan miosin, sehingga tidak terjadi kontraksi.

\section{Reticulum Sarkoplasma.}

$\begin{array}{lr}\text { Dalam } & \text { sarkoplasma } \\ \text { terdapat banyak } & \text { retikulum } \\ \text { endoplasma yang dalam serabut } \\ \text { otot disebut retikulum } \\ \text { sarkoplasma. } & \text { Retikulum }\end{array}$


sarkoplasma ini mempunyai susunan khusus yang sangat penting dalam pengawasan kontraksi otot. Pada otot cepat mempunyai retikulum sarkoplasama lebih banyak dari otot lambat. (Guyton, 1995).

Retikulum sarkoplasma terdiri dari dua bagian penting yaitu, tubulus yang panjang (Longitudinal tubulus) dan ruang besar yang disebut sisterna. Ciri khas dari retikulum sarkoplasma ialah mengandung ion kalsium dengan kosentrasi yang sangat tinggi. Sejumlah ion-ion ini akan terlepas bila sel itu terangsang. Kedua ujung longitudinal tubulus berakhir pada sisterna yang berfungsi penyalur ion kalsium mengelilingi tubulus $\mathrm{T}$, sehingga mempermudah jalan aliran rangsangan dari tubulus $\mathrm{T}$ ke sisterna yang disebut fungsional feet. Ini merupakan struktur yang berbeda dengan badan tubulus utama. Tubulus transfersal disebut sebagai tubulus $\mathrm{T}$ atau sistem $\mathrm{T}$ yang berjalan tegak lurus dengan miofibril. Tubulus $\mathrm{T}$ ini sangat kecil bila dibandingkan dengan tubulus longitudinal. Letaknya diantara ujung tubulus longitudinal yang berurutan dengan pembatas sisterna. Tempat terjadinya hubungan antara tubulus longitudinal dengan tubulus $\mathrm{T}$ disebut triad. Triad terdapat pada tempat terjadinya tumpang tindih antara filamen aktin dan miosin. Dengan demikian, maka setiap sarkomer mempunyai dua triad. Fungsi utama tubulus $\mathrm{T}$ adalah sebagai penyalur potensial aksi yang cepat dari membran sel keseluruh fibril otot (Guyton,1995).

\section{Respon Kontraktil.}

Peristiwa listrik di otot rangka dan aliran ion yang mendasari peristiwa itu serupa dengan yang terjadi di saraf, meskipun berbeda kuantitasdalam hal waktu dan amplitudonya. Potensial membran istirahat otot rangkaadalah sekitar - $90 \mathrm{mV}$. Potensial aksi berlangsung 2-4 mdet dan dihantarkan 
disepanjang serat otot dengan kecepatan kira-kira 5 mdet. Masa refrakter absolutnya 1-3 mdet dan polarisasi ikutan yang berkaitan dengan perubahan ambang terhadap rangsangan listrik relatif lebih panjang (Ganong,1999).

Peristiwa listrik otot penting untuk dibedakan dengan peristiwa-peristiwa mekanisnya. Meskipun respons yang satu secara normal tidak akan terjadi tanpa respons yang lain, namun dasar fisiologik dan sifatsifatnya berbeda. Depolarisasi membran serat otot dalam keadaan normal dimulai diujung (end-plate) otot rangka yang merupakan struktur khusus terdapat di bawah ujung saraf motorik. Potensial aksi dihantarkan disepanjang serat otot dan kemudian membangkitkan respons kontraktil (Ganong,1999).

Mekanisme Kontraksi Otot.

Guyton,1995.

mengemukakan bahwa secara mekanis kontraksi otot adalah terjadinya sliding filamen, sedangkan rangkaian proses kontraksi secara sederhana adalah sebagai berikut :

1. Adanya rangsangan dari otak melalui akson neuron motorik keserabut otot.Rangsangan disampaikan pada akson terminal dan menyebabkan terjadinyapotensial aksi. Selanjutnya terjadi pelepasan asetilkolin dari synaptic visicle pada bagian pre-synaptic ke dalam synaptic gutter.

2. Asetilkolin yang berada disynaptic gutter akan berikatan dengan reseptornyapada sarkolema, sehingga terjadi depolarisasi membran sel otot rangka atauperubahan permeabilitas membran sehingga ion natrium dan kalium keluar. Depolarisasi tersebut menimbulkan potensial aksi membran sel, kemudian disebarkan keseluruh membran sel dan tubulus T.

3. Potensial aksi yang disebarkan dari membran sel akan diteruskan melalui tubulus $\mathrm{T}$. Selanjutnya merangsang terminal sisterna-sarkoplasmik retikulumuntuk melepaskan ion 
kalsium. Ion kalsium akan berikatan dengan troponin Cpada filamen aktin, akibatnya mendorong filamen tropomiosin yang menutup celah-celah aktivesite filamen aktin, sehingga aktivesite terbuka.

\section{Sliding filamen.}

Terbentuknya celah aktive site menyebabkan jembatan penyeberangan (cross bridge) filamen miosin berikatan dengan aktive site filamen aktin. Skematiknya dapat digambarkan sebagai berikut.

Rangsangan Serabut Otot oleh impuls saraf untuk menempel atau balik pada filamen jembatan penyeberangan

tipis pada sudut tertentu.

Rotasi jembatan penyeberangan ke arah/

sudut yang berbeda, untuk itu sliding fila-

men tipis ke arah pusat sarkomer.

Pada waktu ${ }^{\downarrow}$ kontraksi terjadi pemendekan

dari susunan miofibril dan serabut otot

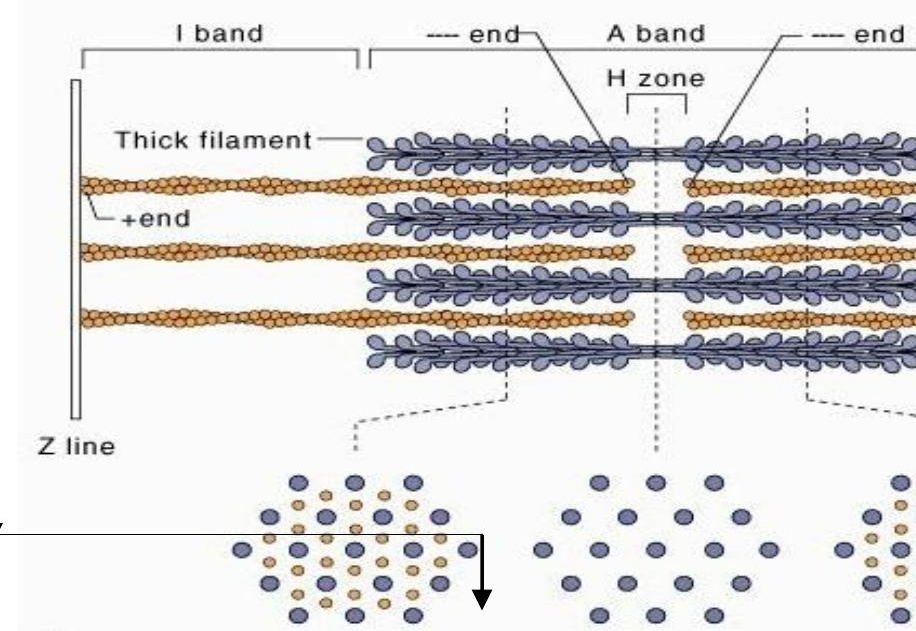

(a)

Copyright 1999 John Wiley and Sons, Inc. All rights reserved.

Mekanisme kontraksi otot (Soekarman, 1987, Guyton, 1995).

Keterangan gambar mekanisme kontraksi otot :

1. Hilangnya zone $\mathrm{H}$ dan mendekatnya garis Z

2. Sabuk I memendek $\downarrow$ karena filamen aktin menempel garis $\mathrm{Z}$ pada sisi lain dari sarkomer dan tertarik ke arah pusat. 
3. Sabuk A tidak mengalami perubahan panjang.

4. Filamen aktin dan miosin tidak terjadi pemendekan dalam mekanisme sliding filamen ini.

Fox, Bowers dan Foss, 1993, membagi lima tahapan proses terjadinya sliding filamen yaitu tahap istirahat, rangsangan berpasangan (exitation coupling),kontraksi, pengisian kembali (recharing) dan tahap relaksasi. Ringkasan proses tersebut dapat dilihat pada tabel berikut :
Proses yang mendasari pemendekan elemen kontraktil di otot adalah pergeseran filamen tipis pada filamen tebal. Lebar pita A tetap, sedangkan garis-garis $\mathrm{Z}$ bergerak saling mendekat ketika berkontraksi dan saling menjauh bila otot diregang. Saat otot memendek filamen tipis dari kedua ujung sarkomer yang berhadapan akan saling mendekat. Pada pemendekan otot filamenfilamen tersebut saling tumpang tindih (Ganong,1999).

Pergeseran selama

\begin{tabular}{|c|c|}
\hline I s t & 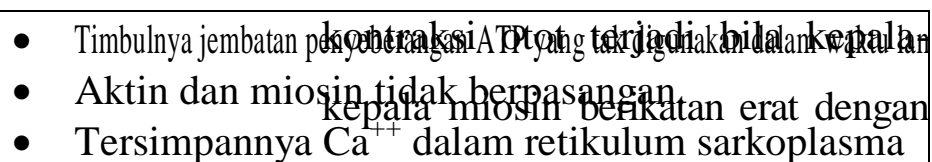 \\
\hline 2. Rangkai & 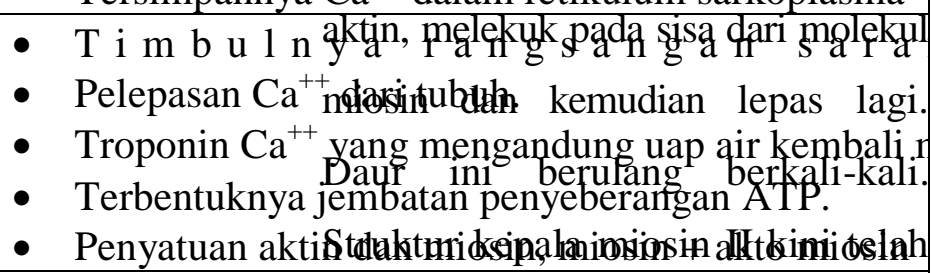 \\
\hline 3. K & 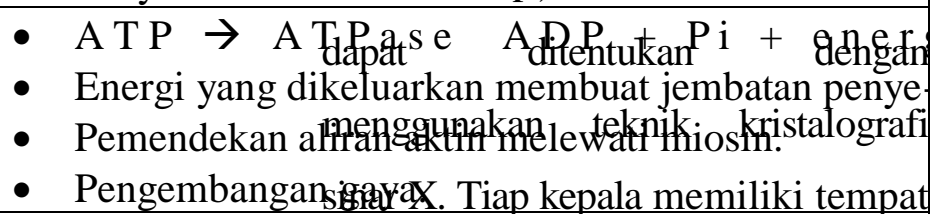 \\
\hline 4. Pengis & 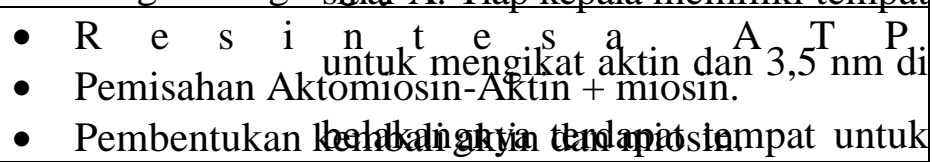 \\
\hline 5. Re la ks a s i & 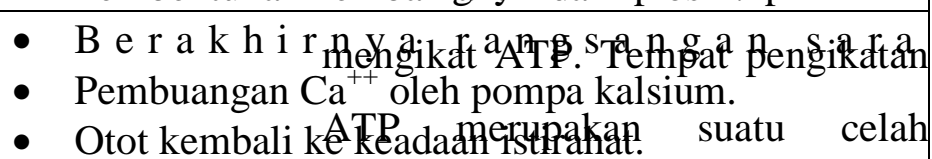 \\
\hline
\end{tabular}
terbuka, dan bila ATP masuk ke Proses (dasar mulekuler) dalamnya dan terhidrolisis, celah akan Kontraksi. tertutup. Hal ini akan mendistorsi sisa kepala miosin yang akan 
melurus menghasilkan “ Kayuhan tenaga “" (Power stroke) yang menggerakan miosin pada aktin. Setiap kayuhan tenaga akan memendekan otot sebesar $1 \%$. Setiap filamen tebal mengandung 500 kepala miosin dan siklus ini terulang $5 \mathrm{x}$ perdetik selama berlangsung kontraksi otot cepat. (Ganong,1999).Perkiraan mekanisme kepala miosin dalam menghasilkan pergeseran aktin-miosin dapat dilihat sebagai berikut :

terbuka. Bila ATP diikat dan terhidrolisis, celah akan tertutup, menyimpangkan kepala miosin, dan kepala miosin tetrikat erat dengan aktin. Kepala miosin kemudian akan mengembalikanpenyimpangan kepala keposisi semula, menghasilkan kayuhan tenaga yang menggerseraktin sepanjang miosin. (Ganong, 1999). Proses penggiatan kontraksi oleh depolarisasi dinamakan proses eksitasi-kontraksi. Potensial aksi dihantarkan keseluruh fibril yang terdapat dalam serat otot melalui

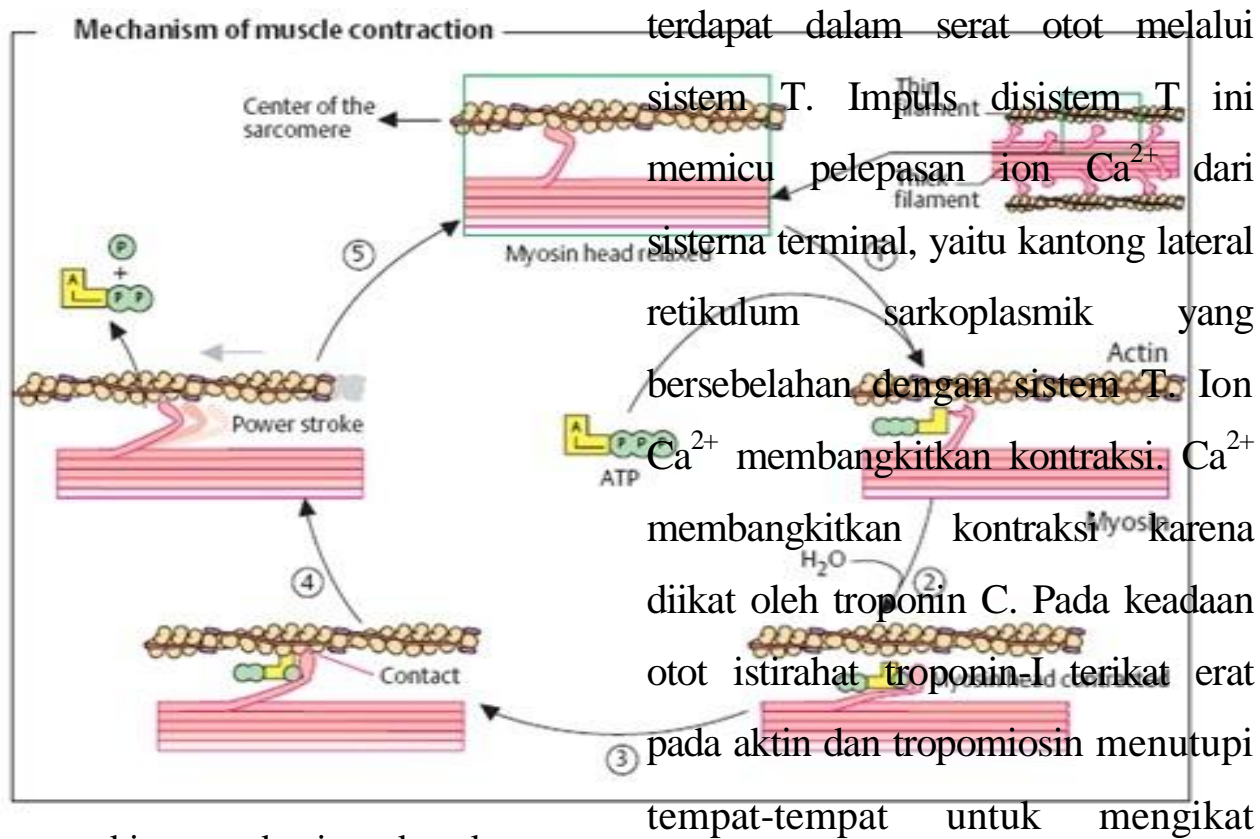

Diagram perkiraan mekanisme kepala miosin dalam menghasilkan pergerseran aktin pada miosin (Ganong, 1999)

\section{Tempat pengikatan ATP} pada kepala miosin merupakan celah kepala miosin dimolekul aktin. Demikian kompleks troponintropomiosin membentuk protein relaksan (relaxing protein) yang menghambat interaksi aktin dengan miosin. Bila ion $\mathrm{Ca}^{2+}$ dilepaskan 
oleh potensial aksi menuju troponin C, ikatan antara troponin-I dengan aktin tampaknya melemah, dan hal ini memungkinkan tropomiosin bergerak ke lateral. Gerakan ini membuka tempat-tempat pengikatan bagi kepala miosin. ATP kemudian terurai dan terjadi kontraksi. Tujuh tempat pengikatan miosin terbuka untuk setiap satu molekul troponin yang mengikat ion kalsium. (Ganong, 1999). Permulaan kontraksi otot oleh $\mathrm{Ca}^{2+}$ dapat dilihat pada gambar berikut :

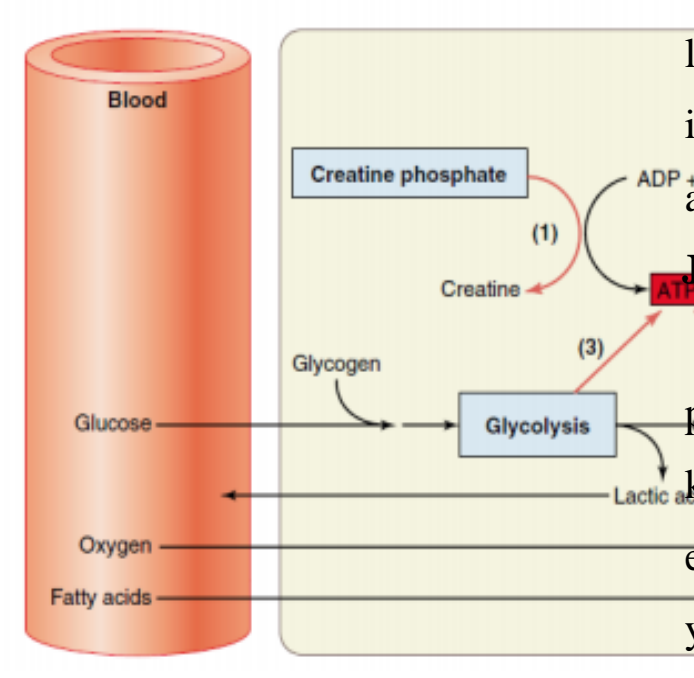

Permulaan kontraksi otot oleh $\mathrm{Ca}^{2+}$, apabila $\mathrm{Ca}^{2+}$ terikat pada troponin $\mathrm{C}$, tropomiosin

bergeser kelateral menyebabkan pemanjangan tempat ikatan miosin pada aktin

(daerah terbuka). (Ganong,1999).

Hidrolisis ATP mengubah konformasi kepala miosin dan membantunya perikatan pada daerah yang terpanjang. Untuk memudahkan, hanya satu dari dua kepala molekul miosin-II yang diperlihatkan (Ganong,1999).Segera setelah melepaskan $\mathrm{Ca}^{2+} \quad$ retikulum sarkoplasmik mulai mengembalikan $\mathrm{Ca}^{2+}$ melalui mekanis transpor aktif ke dalam bagian longitudinal retikulum. Pompa tersebut adalah $\mathrm{Ca}^{2+}-\mathrm{Mg}^{2+}-$ ATPase. $\mathrm{Ca}^{2+}$ kemudian berdifusi ke dalam sisterna terminal (tempat penyimpananya) sampai dilepaskan oleh potensial aksi berikutnya. $\mathrm{Ca}^{2+} \mathrm{di}$ luar retikulum sudah cukup prendah, $_{\text {acter }}$ interaksi kimiawi antara miosin dan aktin terhentipdan otot relaksasi. Jenis-jenis Kontraksi.

pemenpdiekan kontraktil. Karena Fotootidmempunyai elemen-elemen elastik dan kenyal yang tersusun seri dengan mekanisme kontraksi, maka kontraksi dapat terjadi tanpa pemendekan yang berarti diseluruh berkas otot. Kontraksi semacam itu disebut kontraksi “ Isometrik " (dengan ukuran yang sama atau dengan panjang yang sama). Kontraksi melawan beban yang 
tetap dengan pemendekan otot dinamakan kontraksi "Isotonik" (tegangan yang sama). Karena kerja merupakan hasil perkalian gaya dan jarak, maka kontraksi isotonik menghasilkan kerja, sedangkan isometrik tidak. Pada keadaan lain otot dapat melakukan kerja negatif pada saat kontraksi. Hal ini dapat terjadi bila suatu beban berat diletakan di atas meja, otot secara aktif menahan turunnya objek, tetapi efek keseluruhannya adalah pemanjangan otot saat berkontraksi (Ganong, 1999). Sediaan otot yang disusun untuk kontraksi isotonik dan isometrik dapat dilihat sebagai berikut :

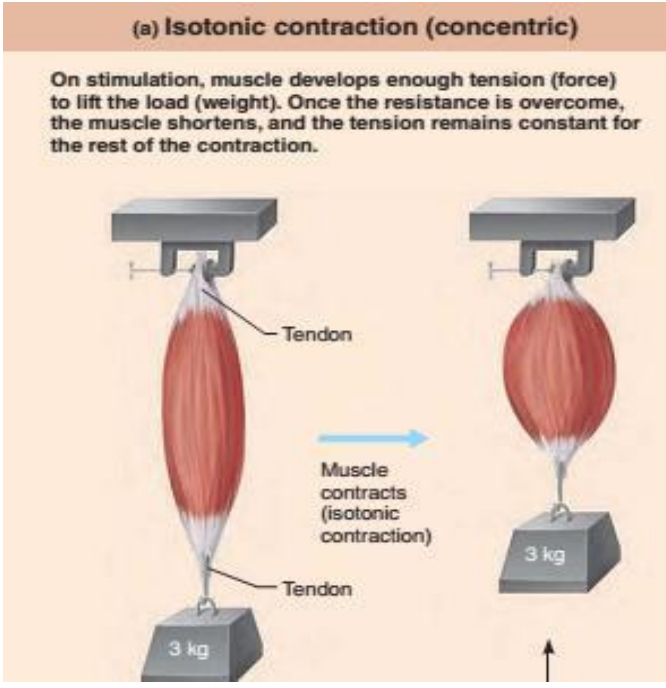

A. sediaan otot yang disusun untuk rekaman kontraksi isotonik.

$\mathrm{B}$, sediaan otot yang disusun untuk rekaman kontraksi isometrik.
Pada A, otot di fiksasi pada tuas pengungkit yang berayun pada titik putar. Pada B, otot difiksasi pada tranduser elektronik yang mengukur gaya yang dihasilkan pada kontraksi tanpa pemendekan otot (Ganong, 1999).

Costil, 1982

Berger,1983. mengemukakan ada tiga jenis kontraksi otot yaitu kontraksi cocentrik, isometrik dan eccentrik. Soekarman, 1987 menyatakan terdapat empat macam kontraksi otot yaitu kontraksi isotonik, isometrik, eksentrik dan isokinetik. Lebih lanjut ia menjelsakan bahwa kontraksi isotonik disebut juga kontraksi cocentrik atau dimanik. Misalnya pada flexi lengan atau tungkai, origo dan insertio saling mendekat. Kontraksi (b) Isometric contraction isometrik tidak kelihatan adanya Muscle is attached to a weight that exceeds the muscle's peak tension-developing capabilitięs. When stimulated, the capability, but the muscle does noj

kontraksi statis. Mempertahankan sikap túbuh adalah salah sâtu dari kontraksi isometrik. Pada kontraksi ini tidak terjadi perubahan panjang otot. Pada ckoscle $\begin{gathered}\text { Montraksi eksentrik } \\ \text { (isometric }\end{gathered}$ biasanya terjadi pemendekatan atau pemanjangan otot secara tetap. Kontraksi isokinetik, tegangan yang timbul di otot yaitu pada waktu terjadinya pemendekan dengan 
kecepatan (kinetik) yang sama (iso), sehingga dinamakan kontraksi isokinetik.Ganong,1999 mengemukakan beberapa hal yang berperan dalam kontraksi dan relaksasi otot rangka sebagai berikut :

\section{Tahap-Tahap Kontraksi.}

(1) Penggiatan neuron motorik, (2) pelepasan transmiter (asetilkolin) di End-plate motorik, (3) pengikatan asetilkolin oleh reseptor asetilkolin nikotinikm (4) peningkatan konduktans $\mathrm{Na}^{+}$ dan $\mathrm{K}^{+}$di membran Endplate, (5) terbentuknya potensial End-plate, (6) tercetusnya potensial aksi rangka melekat pada tulang dan diserat-serat otot, (7) berperan sebagai sistem perototan, penyebaran depolarisasi ke yaitu menggerakan tubuh. Aktivitasnya dalam tubulus $\mathrm{T}$, (8) diatur oleh susunan saraf melalui pelepasan $\mathrm{Ca}^{2+}$ dari sisterna persarafan motorik. Setiap serabut saraf terminal retikulum sarkoplasmik serta difusi $\mathrm{Ca}^{2+}$ ke filamen tebal dan filamen tipis, (9) pengikatan $\mathrm{Ca}^{2+}$ oleh troponin $\mathrm{C}$ membuka tempat pengikatan miosin di molekul aktin, (10) pembentukan potensial pada serabut otot dapat ikatan silang (cross linkage)

antara aktin dan miosin dan pergeseran filamen tipis pada filamen tebal, menghasilkan pemendekan.

\section{Tahap-Tahap Relaksasi.}

(1) $\mathrm{Ca}^{2+}$ dipompakan kembali ke dalam retikulum sarkoplasma, (2) pelepasan $\mathrm{Ca}^{2+}$ dari troponin, dan (3) pengikatan interaksi antara aktin dan miosin.

\section{Penutup (Simpulan)}

Otot merupakan jaringan peka yang dapat dirangsang untuk motorik terbagi menjadi sejumlah cabang yang akan mengadakan kontak langsung dengan serabut otot disebut sebagai neuro muscular junction. Hubungan saraf otot ini terjadi pada bagian tengah otot, sehingga aksi 
menyebar kesemua arah, selanjutnya terjadilah kontraksi.

Mempedomani beberapa pendapat dari para ahli yang telah dikutip dan dipapar di atas, maka dapat disimpulkan bahwa kontraksi otot rangka ditentukan/dipengaruhi oleh berbagai faktor, di mana satu unsur dengan yang lainnya merupakan sesuatu yang saling mendukung. Berbagai faktor dimaksud antara lain sistem neuromuscular, penyediaan energi, mobiliylitas saraf, viskositas dan koordinasi otot.

\section{BIO DATA PENULIS}

Madri. M, Drs, M.Kes, AIFO. Lahir di Pesisir Selatan 16 September 1960. Dosen Jurusan Pendidikan Olahraga Fakultas Ilmu Keolahragaan Universitas Negeri Padang. Meraih gelar Sarjana Pendidikan Olahraga di FPOK-IKIP Padang tahun 1995 dan Magister Ilmu Kesehatan Olahraga (IKOR) di Pascasarjana Universitas Airlangga Surabaya tahun 2005 
Daftar Pustaka.

Amstrong RB, 1979. Energi Liberation and use in sport Medicine and Physiology, Edeted by Strause R.H ; Philadelphia, WB Sounders Company.

Berger, RA, 1982. Applied Exercise Physiology ; Philadelphia, Lea Feveger.

Bowers RW, 1992. Sport Physiology, $3^{\text {rd }}$-ed ; New York, Wm C Brown Pub.

Brooks, GA, Thomas D. Fahay, 1985. Physiologycal Exercise, Human Bioenergetics and Ist Applications ; New York, Mac Millan Publishing Company.

Costell, dkk,1982. Adaptions in Skelet Muscle Following Training ; JAppl, Physiol, Respirant, Environ Exercise Physiol.

Fox, El, Bowers RW, Foss ML, 1993. The Physiologycal Basis of Physical Education and Athletics, $4^{\text {th }}$-ed ; Philadelphia, Sounders College Pub.

Ganong F, William, 1999. Fisiologi Kedokteran Edisi-17 (editor bahasa Indonesia, Dr.M. Djauhari Widjayakusumah) ; San Fransisca, Jack and Deloris Profesor of Physiology Emeritus.

Guyton, AC,1995. Texbook of Medical Physiology, $\quad 8^{\text {th }}$-ed ; Philadelphia, WB Sounders Company.
Janssen, GJM P,1989. Latihan Laktat Denyut Nadi (traing Lactate Pulse Rate) Editor ahli edisi Indonesia, KS. Mutalib ; Jakarta, Koni DKI Jaya.

McArdle, WD, dkk,1986. Exercese Physiology Energy Nutrition and Human Performance Energy Transfer in the Body, $2^{\text {nd }}$-ed ; Philadelphia, Lea \& Febeger.

Soekarman, R, 1987. Dasar Olahraga untuk Pembina, Pelatih dan Atlet ; Jakarta, Intidaya Press.

Stryer, L, 1988. Biochemistry, $3^{\text {rd }}$-ed ; New York, WH Freeman and Company 
grup fosfat dengan melepaskan

B. Sumber

energi

\&

Metabolisme.

Kontraksi

otot

membutuhkan energi, dan otot disebut sebagai mesin pe-ngubah energi kimia menjadi kerja mekanis. Sumber energi yang dapat segera di-gunakan adalah derivat fosfat organik berenergi tinggi yang terdapat di otot. Sumber utama energi diperoleh dari metabolisme intermedier karbohidrat dan lipid (Ganong,1999).

\section{Fosforilkreatin.}

Ganong,
menyatakan bahwa
disentesis ulang dari ADP
dengan penambahan satu grup
fosfat. Sebagian besar energi
yang dibutuhkan untuk reaksi
ini diperoleh dari penguraian
glukosa menjadi $\mathrm{CO}_{2}$ dan $\mathrm{H}_{2} \mathrm{O}$
tetapi di otot juga ada senyawa
fosfat berenergi tinggi lain yang
dapat memasok energi yang
dibutuhkan ini untuk jangka
pendek. Senyawa fosfat itu
adalah fosforil kreatin yang
dihidrolisis menjadi kreatin dan

sejumlah besar energi.

Dalam keadaan

istirahat sebagian ATP di mitokondria melepaskan fosfatnya kepada kreatin, sehingga terbentuk simpanan

fosforilkreatin. Pada waktu kerja fosforilkreatin ini mengalami hidrolisis ditempat pertemuan kepala miosin dengan aktin, membentuk ATP dan ADP yang menyebabkan proses kontraksi dapat berlanjut. Peranan ATP sebagai sumber energi langsung untuk aktivitas otot, berlangsung secara siklus (Striyer, 1988, Bower, 1992, Guyton, 1995). Proses pembentukan ATP dalam otot diperoleh melalui sistem ATPPC (sistem Phosfagen), glikolisis anaerobik (sistem asam laktat) dan sistem aerobik yang terdiri dari oksidasi karbohidrat, lemak dan protein. (Amstrong, 1979, McArdle, 1986, Jansen, 1989, Fox, 1993).

Sistem ATP-PC dan sistem asam laktat disebut juga sistem anaerobik, karena kedua 
sistem ini tidak memerlukan oksigen. Jansen, 1989 mengatakan sistem anaerobik alaktik adalah untuk sistem phosfagen dan anaerobik laktik untuk sistem asam laktat.

\section{Sistem Fosfagen.}

Sistem ini merupakan pemasok energi paling cepat untuk aktivitas otot, tetapi tidak bertahan lama. Ini disebabkan karena ATP maupun PC (Phosfo creatin) tersedia dalam jumlah terbatas dalam otot dan hanya memerlukan rang-kaian reaksi kimia yang pendek untuk mengubah menjadi energi yang langsung digunakan otot melakukan aktivitas. ATP dan PC tertimbun di otot hanya cukup digunakan dalam aktivitas maksimum selama 2030 detik (McArdle, 1986, Bowers, 1992). Oleh karena itu sistem fosfagen ini sangat berguna untuk gerakan mendadak atau olahraga kecepatan tinggi dan berlangsung singkat. Bila sistem fosfagen habis dan aktivitas otot tetap harus dilanjutkan, maka energi akan di-peroleh dari sistem glikolisis anaerobik (sistem asam laktat). Sebaliknya bila akti-vitas dihentikan, maka segera terjadi pemulihan dimana cadangan ATP-PC dikembalikan pada keadaan semula.

\section{Sistem Asam laktat.}

Sistem ini mengubah glukosa yang ada di sitoplasma sel otot menjadi energi dan asam laktat. Sistem ini menghasilkan dua molekul ATP per molekul glukosa (3 molekul ATP permolekul glikogen), ini terjadi bila mitokondria mengalami kekurangan oksigen, asam piruvat yang seharusnya masuk ke dalam mitokondria berubah menjadi asam laktat (Amstrong, 1979, Brooks, 1985, Mc Ardle, 1986).

Aktivitas yang berlanjut lama akan menyebabkan glikolisis anaerobik terus berputar hingga produksi laktat bertumpuk. Hal ini menyebabkan menurun-nya $\mathrm{Ph}$ (meningkatnya keasaman) 
dalam otot maupun darah yang akhirnya meng-hambat enzym dan reaksi kimia dalam sel otot itu sendiri, sehingga menyebabkan kontraksi otot menjadi lemah dan akhirnya mengalami kelelahan (Mc Ardle, 1986, Janson, 1989, Fox, 1993). Asam laktat pada serabut otot yang aktif akan masuk ke dalam darah menuju sitoplasma otot yang aktif, selanjutnya berubah menjadi asam piruvat. Asam piruvat ini masuk ke mitokondria mengalami suatu rangkaian proses oksidasi (siklus kreb dan sistem transfer elektron) menghasilkan ATP, $\mathrm{H}_{2} \mathrm{O}$ dan $\mathrm{C}_{2} \mathrm{O}$. Proses ini dikenal sebagai proses oksidasi asam laktat.

\section{Sistem energi aerobik}

Sistem ini meliputi oksidasi karbohidrat, lemak dan protein yang ber-langsung di mitokondria melalui serangkaian proses pada siklus kreb dan sistem transfer elektron. Apabila dalam mitokondria mempunyai cukup banyak oksigen, maka glikogen di sitoplasma diubah menjadi asam piruvat. Asam piruvat selan-jutnya masuk ke dalam mitokondria dan bersama Co enzym A (CoA) membentuk asetil CoA. Acetil CoA membentuk asam sitrat yang selanjutnya mengalami serangkaian reaksi kimia disiklus kreb, Dalam siklus ini terbentuk $\mathrm{CO}_{2}$ dan bebe-rapa ATP.

Siklus kreb berperan sebagai jalan lintas bagianbagian senyawa organik dari hasil pemecahan lemak atau protein yang diproses secara efektif untuk meng-hasilkan energi resintesa ATP. Energi (ATP) yang dihasailkan oleh proses oksi-dasi ini jauh lebih banyak dibanding dengan proses glikolisis anaerobik. Oksidasi satu molekol glukosa menghasilkan 38 ATP dan satu molekul glikogen menghasilkan 39 ATP. Oksidasi lemak (satu molekul trigliserida) menghasilkan 463 ATP, sementara oksidasi protein hanya terjadi pada keadaan yang mendesak (McArdle, 1986, 
Stryer, 1988, Ganong,1999,

Guyton,1995). 